\title{
The use of Newton's method for interpolation in the bench testing of compression-ignition engine unit injector systems
}

\begin{abstract}
The paper presents the methodology for calculations based on the Newton's method which was used to determine the characteristics of test unit injector systems. It allowed simplification of the research process by preserving a minimum number of measuring points and estimation of other data analytically. Results were compared with the real experimental results obtaining satisfactory accuracy of approximations. The proposed methodology was adapted to a standard spreadsheet so that changes in pre-set parameters and required computations could be made on a regular basis, which in addition shortened the time of their performance.
\end{abstract}

Key words: diesel engine, polynomial interpolation, unit injector system

\section{Wykorzystanie interpolacyjnej metody Newtona w badaniach stanowiskowych pompowtryskiwaczy silnika o zapłonie samoczynnym}

\begin{abstract}
W artykule przedstawiono metodykę obliczeń oparta na metodzie Newtona, która zastosowano do wyznaczenia charakterystyk probierczych pompowtryskiwaczy. Umożliwita ona uproszczenie procesu badawczego przez zachowanie minimalnej liczby punktów pomiarowych i oszacowanie pozostatych danych w sposób analityczny. Rezultaty odniesiono do rzeczywistych wyników doświadczalnych, uzyskując zadowalająca dokładność przybliżen. Proponowanq metodykę zaadaptowano do standardowego arkusza kalkulacyjnego, dzięki czemu zmianę parametrów zadanych $i$ wymagane obliczenia prowadzono na bieżaco, co dodatkowo skróciło czas ich realizacji.
\end{abstract}

Słowa kluczowe: silnik wysokoprężny, interpolacja wielomianowa, pompowtryskiwacze

\section{Introduction}

Since the middle of the nineties of the $20^{\text {th }}$ century, individual electronically controlled pump injection systems have been brought into use in compression-ignition engines, being called unit injector systems (UIS). Their predominant role has been ended by widespread use of Common Rail fuel injection systems, nevertheless they have been produced until now in the sector of heavy duty vehicles. This has been shown by engine designs meeting the most recent exhaust emission standards, including Euro 6 emission standard being currently introduced, e.g. Volvo D13 and Renault Trucks DTI13. In order to meet these requirements, manufacturers use additional systems, including exhaust gas recirculation (EGR) and selective catalytic reduction (SCR) [4, 13]. The most important advantages of unit injector systems are durability and reliability which are particularly desirable for substantial mileages and intense operation. Long laboratory and service station experience show that, in this aspect, they outrun Common Rail injectors which are considered the most failure-prone elements of fuel supply systems $[6,9,12]$. In addition, third generation of unit injector systems, has optimized design by the introduction of two-valve operation mode, which have enabled precise shaping of fuel injection at a pressure range of above $200 \mathrm{MPa}$, e.g. Bosch UIS3 and Delphi E3. Therefore, it is possible to assume that maintenance and repair of unit injector systems of different type and manufacture will be necessary for many years.

\section{Research objective}

At present, classical interpolation formulas are used occasionally, constituting the starting point for sophisticated

\section{Wstęp}

Od połowy lat dziewięćdziesiątych XX wieku w silnikach o zapłonie samoczynnym zaczęto stosować indywidualne układy tłocząco-wtryskowe sterowane elektronicznie, które nazwano pompowtryskiwaczami. Ich dominującą rolę zakończyło rozpowszechnienie systemów zasobnikowych, jednak w sektorze pojazdów użytkowych są one nadal produkowane. Świadczą o tym konstrukcje silników, np. Volvo D13, Renault Trucks DTI13, spełniające najbardziej rygorystyczne normy toksyczności gazów wylotowych, w tym aktualnie wprowadzona Euro 6. Aby sprostać tym wymaganiom, producenci wykorzystują dodatkowe układy, w tym m.in.: recyrkulacji spalin EGR (Exhaust Gas Recirculation) i selektywnej redukcji katalitycznej SCR (Selective Catalityc Reduction) [4, 13]. Do najważniejszych zalet pompowtryskiwaczy należy duża trwałość i niezawodność, szczególnie pożądane przy znacznych przebiegach oraz intensywnej eksploatacji. Wieloletnia praktyka laboratoryjna i warsztatowa wskazuje, iż w tym aspekcie ,przewyższają" one wtryskiwacze common rail, które uważa się za najbardziej awaryjne elementy układów podawania paliwa $[6,9,12]$. Ponadto konstrukcje trzeciej generacji, np. Bosch UIS3, Delphi E3, których optymalizacja polegała na wprowadzeniu dwuzaworowego trybu pracy, umożliwiły precyzyjne kształtowanie wtrysku paliwa pod ciśnieniem powyżej 200 MPa. Można więc założyć, iż przez wiele lat będzie zachodziła konieczność obsługi i naprawy pompowtryskiwaczy różnych rodzajów oraz różnych producentów.

\section{Cel badań}

Obecnie klasyczne wzory interpolacyjne wykorzystywane są sporadycznie, stanowiąc bazę wyjściową dla 
numerical methods. However, there are areas where application of simplified computations may bring measurable benefits. As an example, a few characteristics of injection systems being obtained during time-consuming and burdensome tests, with repeated experimental cycles were obtained. In this connection, a concept concerning the limitation of the number of measuring points occurred and then the missing data with required accuracy of approximations should be computed.

This study aimed at cognitive evaluation of the possibility of repairing electromagnetic unit injector systems (UIS) using Newton's interpolation at the stage of bench tests. Selection of the method was dictated by the necessity to preserve unequal distances intervals between measuring points. The possibility of easy adaptation to a standard spreadsheet, i.e. to performing regular computations, was also taken into account.

\section{Research object and test bench}

The research object was Bosch electromagnetic unit injector system which has been removed from 1.9 TDI (Turbodiesel Direct Injection) power unit of a commercial vehicle Volkswagen Transporter T5 with a mileage of 269 thousand $\mathrm{km}$. It is an in-line, four cylinder Diesel engine with a maximum power of $77 \mathrm{~kW}$.

Bench tests were conducted on an STP-4 test bench manufactured by the Automotive Industry Training Centre „Autoelektrotechnika Kędzia” from Poznan, which enables simulation of engine speed in the range of 100-1500 rpm. In addition, the following equipment was used during verification and repair:

a) Bosch EPS 100 pressure tester with a head mounting holder for unit injector system,

b) Meiji FL150/70 microscope with a camera for digital image recording,

c) universal gauges (BM800, MIC-40700),

d) ultrasonic cleaners (Carbon Tech Ultrasonic Bath S15/ C2, Elma Elmasonic S $10 \mathrm{H}$ ),

e) vices and injector disassembly and assembly kits.

Test bench measurements were performed at the following engine speeds $n[\mathrm{rpm}]: \mathrm{x}_{0}=400, \mathrm{x}_{2}=800, \mathrm{x}_{4}=1500$. The obtained data, being expanded with the results of computations for indirect operands, were used to determine the characteristics of fuel dosing for the tested unit injectors.

\section{Scope of research and test methods}

Tests were carried out according to the adopted own methodology which included two successive stages (Fig. 1). In the first stage, called a repair stage, the scope of activities partially overlaps Bosch standard procedures. A difference consisted in earlier examination and verification of particular elements because available equipment enabled detection of defects prior to cleaning in ultrasonic bath-tubes. With this, the cleaning process did not include faulty elements which were substituted with original replacements.

Stage II has started with regulation of the opening pressure of unit injector systems after repair. The tests has been continued after injectors assembling on the test bench, us- skomplikowanych metod numerycznych. Istnieją jednak obszary, w których zastosowanie uproszczonego aparatu obliczeniowego może przynieść wymierne korzyści, np. charakterystyki aparatury wtryskowej, uzyskiwane w procesie czasochłonnych i uciążliwych badań eksploatacyjnych, przy wielokrotnie powtarzanych cyklach eksperymentu. W związku z tym pojawiła się koncepcja ograniczenia liczby punktów pomiarowych, a następnie obliczenia brakujących danych z wymaganą dokładnością przybliżeń.

Celem badań była poznawcza ocena możliwości naprawy pompowtryskiwaczy elektromagnetycznych UIS (Unit Injector System), przy wykorzystaniu interpolacji Newtona w fazie testów probierczych. Wybór metody podyktowany był koniecznością zachowania nierównych odstępów między punktami pomiarowymi. Brano również pod uwagę możliwość łatwej adaptacji do standardowego arkusza kalkulacyjnego, a więc prowadzenie bieżących obliczeń.

\section{Obiekt i stanowiska badawcze}

Obiekt badań stanowiły pompowtryskiwacze elektromagnetyczne firmy Bosch, które wymontowano z jednostki napędowej 1,9 TDI (Turbodiesel Direct Injection) pojazdu dostawczego Volkswagen Transporter T5 o przebiegu 269 tys. km. Jest to wysokoprężny silnik czterocylindrowy, rzędowy, o maksymalnej mocy $77 \mathrm{~kW}$.

Testy probiercze prowadzono na stole typu STP-4 produkcji Centrum Szkolenia Motoryzacji „Autoelektrotechnika Kędzia" z Poznania, który umożliwia uzyskanie stabilizowanych prędkości obrotowych w zakresie 100-1500 obr/min. W procesie weryfikacji i naprawy wykorzystano dodatkowo:

a) próbnik ciśnienia Bosch EPS 100 z obsadą głowicową dla pompowtryskiwaczy,

b) mikroskop Meiji FL150/70 z kamerą do cyfrowego zapisu obrazów,

c) mierniki uniwersalne (BM800, MIC-40700),

d) myjki ultradźwiękowe (Carbon Tech Ultrasonic Bath S15/ C2, Elma Elmasonic S $10 \mathrm{H}$,),

e) imadła i oprzyrządowanie do demontażu oraz montażu pompowtryskiwaczy.

Pomiary stanowiskowe prowadzono przy następujących prędkościach obrotowych $\mathrm{n}$ [obr/min]: $\mathrm{x}_{0}=400$, $\mathrm{x}_{2}=800, \mathrm{x}_{4}=1500$. Uzyskane wyniki, które poszerzono o rezultaty obliczeń dla argumentów pośrednich, posłużyły do wyznaczenia charakterystyk dawkowania badanych pompowtryskiwaczy.

\section{Zakres i metodyka badań}

Badania prowadzono według przyjętej metodyki własnej, która obejmowała dwa etapy realizacji (rys. 1). W pierwszym, który określić można jako naprawczy, zakres czynności częściowo pokrywał się ze standardowymi procedurami firmy Bosch. Różnica polegała na wcześniejszych oględzinach i weryfikacji poszczególnych elementów, gdyż dostępne wyposażenie umożliwiało wykrycie uszkodzeń przed fazą mycia w wannach ultradźwiękowych. W ten sposób proces czyszczenia nie obejmował elementów niesprawnych, które zastąpiono oryginalnymi zamiennikami. 
ing the same procedure as in the initial stage. In both cases, the Newton's formula has been used to estimate the values of indirect operands so that the time of experiment was effectively shortened.

\section{Computations}

The problem of interpolation is to find a function, taking given pre-set values at precisely determined points (i.e. nodes), within a specific range. In the previously carried study, which referred to determination of the external characteristics of compression-ignition engine, the Lagrange formula and the Aitken iterative scheme were used [11]. Because the procedure of bench tests for unit injector systems demands the measurements to be made with preserved unequal distances intervals between operands, it was decided to apply the methodology based on Newton's interpolation [2, 3, 14]. The n-th degree polynomial $\mathrm{W}_{\mathrm{n}}(\mathrm{x})$ used to the interpolation, may be presented as the sum of individual components, which allows adding successive nodes without the need for recalculation of its earlier elements:

$$
\begin{gathered}
\mathrm{W}_{\mathrm{n}}(\mathrm{x})=\mathrm{f}\left(\mathrm{x}_{0}\right)+\mathrm{f}\left(\mathrm{x}_{0} ; \mathrm{x}_{1}\right) \omega_{0}(\mathrm{x})+\mathrm{f}\left(\mathrm{x}_{0} ; \mathrm{x}_{1} ; \mathrm{x}_{2}\right) \omega_{1}(\mathrm{x})+ \\
+\ldots+\mathrm{f}\left(\mathrm{x}_{0} ; \mathrm{x}_{1} ; \ldots ; \mathrm{x}_{\mathrm{n}}\right) \omega_{\mathrm{n}-1}(\mathrm{x})
\end{gathered}
$$

where: $\mathrm{x}_{0}, \mathrm{x}_{1}, \mathrm{x}_{2}, \ldots, \mathrm{x}_{\mathrm{n}}$ - measuring points (main nodes), $\mathrm{f}\left(\mathrm{x}_{0}\right)$ - function value at point $\mathrm{x}_{0}, \mathrm{f}\left(\mathrm{x}_{0} ; \mathrm{x}_{1}\right), \mathrm{f}\left(\mathrm{x}_{0} ; \mathrm{x}_{1} ; \mathrm{x}_{2}\right)$, $\mathrm{f}\left(\mathrm{x}_{0} ; \mathrm{x}_{1} ; \ldots ; \mathrm{x}_{\mathrm{n}}\right)$ - difference quotients for successive rows, $\omega_{0}(\mathrm{x})=\left(\mathrm{x}-\mathrm{x}_{0}\right), \omega_{1}(\mathrm{x})=\left(\mathrm{x}-\mathrm{x}_{0}\right)\left(\mathrm{x}-\mathrm{x}_{1}\right), \omega_{\mathrm{n}-1}(\mathrm{x})=\left(\mathrm{x}-\mathrm{x}_{0}\right)\left(\mathrm{x}-\mathrm{x}_{1}\right) \ldots$ $\left(\mathrm{x}-\mathrm{x}_{\mathrm{n}-1}\right)$ - factorial polynomials.

According to equation (1) for determination of the final form of polynomial, the values of difference quotients should be calculated, being best presented in numerical calculations as tabulated (tab. 1).

\section{Research results and discussion}

The initial examination of unit injector systems did not show external damages and missing components. The measurements of inductance and resistance excluded solenoid coil fault, as well as short to ground. As a result, the stage of initial tests on an STP-4 test bench started. The selection of main nodes and indirect points was dictated solely by assumptions of the procedure being used for the testing of Bosch

Table 1. Presentation of difference quotients for successive rows Tabela 1. Sposób prezentacji ilorazów różnicowych kolejnych rzędów

\begin{tabular}{|c|c|c|c|c|}
\hline \multirow{2}{*}{$\mathrm{x}_{\mathrm{i}}$} & $\mathrm{f}\left(\mathrm{x}_{\mathrm{i}}\right)$ & \multicolumn{3}{|c|}{ Difference quotients/ilorazy różnicowe } \\
\cline { 3 - 5 } & & $\mathrm{f}\left(\mathrm{x}_{\mathrm{i}-1} ; \mathrm{x}_{\mathrm{i}}\right)$ & $\mathrm{f}\left(\mathrm{x}_{\mathrm{n}-2} ; \mathrm{x}_{\mathrm{n}-1} ; \mathrm{x}_{\mathrm{i}}\right)$ & $\mathrm{f}\left(\mathrm{x}_{\mathrm{i}-\mathrm{n}} ; \ldots ; \mathrm{x}_{\mathrm{i}}\right)$ \\
\hline $\mathrm{x}_{0}$ & $\mathrm{f}\left(\mathrm{x}_{0}\right)$ & - & - & - \\
\hline $\mathrm{x}_{1}$ & $\mathrm{f}\left(\mathrm{x}_{1}\right)$ & $\mathrm{f}\left(\mathrm{x}_{0} ; \mathrm{x}_{1}\right)$ & - & - \\
\hline $\mathrm{x}_{2}$ & $\mathrm{f}\left(\mathrm{x}_{2}\right)$ & $\mathrm{f}\left(\mathrm{x}_{1} ; \mathrm{x}_{2}\right)$ & $\mathrm{f}\left(\mathrm{x}_{0} ; \mathrm{x}_{1} ; \mathrm{x}_{2}\right)$ & - \\
\hline$\ldots$ & $\ldots$ & $\ldots$ & $\ldots$ & $\ldots$ \\
\hline $\mathrm{x}_{\mathrm{n}}$ & $\mathrm{f}\left(\mathrm{x}_{\mathrm{n}}\right)$ & $\mathrm{f}\left(\mathrm{x}_{\mathrm{n}-1} ; \mathrm{x}_{\mathrm{n}}\right)$ & $\mathrm{f}\left(\mathrm{x}_{\mathrm{n}-2} ; \mathrm{x}_{\mathrm{n}-1} ; \mathrm{x}_{2}\right)$ & $\mathrm{f}\left(\mathrm{x}_{0} ; \ldots ; \mathrm{x}_{\mathrm{n}}\right)$ \\
\hline
\end{tabular}

Fig. 1. Methodology of unit injector system tests

Rys. 1. Metodyka badań pompowtryskiwaczy

Etap drugi rozpoczynał się od regulacji ciśnienia otwarcia pompowtryskiwaczy po naprawie. Po montażu ponownie przeprowadzono testy probiercze, stosując taką samą procedurę jak w fazie wstępnej. W obu przypadkach do oszacowania wartości argumentów pośrednich posłużono się wzorem Newtona, dzięki czemu efektywnie skrócono czas przeprowadzonego eksperymentu.

\section{Aparat obliczeniowy}

Zagadnienie interpolacji polega na znalezieniu w określonym przedziale funkcji, która przyjmuje odgórnie zadane wartości w ściśle określonych punktach, tzw. węzłach. We wcześniej prowadzonych badaniach własnych, które dotyczyły wyznaczania charakterystyk zewnętrznych silnika o zapłonie samoczynnym, wykorzystywano do tego celu wzór Lagrange`a oraz iteracyjny schemat Aitkena [11]. Ponieważ procedura testów probierczych pompowtryskiwaczy wymusza prowadzenie pomiarów przy zachowaniu nierównych odstępów między argumentami, zdecydowano się na zastosowanie metodyki opartej na interpolacji Newtona [2, 3, 14]. Wielomian interpolacyjny $\mathrm{W}_{\mathrm{n}}(\mathrm{x}) \mathrm{n}$-tego stopnia można przedstawić w postaci sumy poszczególnych składników, co umożliwia dodawanie kolejnych węzłów, bez konieczności ponownego przeliczania jego wcześniejszych elementów (1), gdzie: $\mathrm{x}_{0}, \mathrm{x}_{1}, \mathrm{x}_{2}, \ldots, \mathrm{x}_{\mathrm{n}}$ - punkty pomiarowe (węzły główne), $\mathrm{f}\left(\mathrm{x}_{0}\right)$ - wartość funkcji w punkcie $\mathrm{x}_{0}, \mathrm{f}\left(\mathrm{x}_{0} ; \mathrm{x}_{1}\right), \mathrm{f}\left(\mathrm{x}_{0} ; \mathrm{x}_{1} ; \mathrm{x}_{2}\right)$, $\mathrm{f}\left(\mathrm{x}_{0} ; \mathrm{x}_{1} ; \ldots ; \mathrm{x}_{\mathrm{n}}\right)-$ ilorazy różnicowe kolejnych rzędów, $\omega_{0}(x)=\left(x-x_{0}\right), \omega_{1}(x)=\left(x-x_{0}\right)\left(x-x_{1}\right), \omega_{n-1}(x)=\left(x-x_{0}\right)\left(x-x_{1}\right) \ldots$ $\left(\mathrm{x}-\mathrm{x}_{\mathrm{n}-1}\right)$ - wielomiany czynnikowe.

Zgodnie ze wzorem (1) do wyznaczenia końcowej postaci wielomianu należy obliczyć wartości ilorazów różnicowych, które przy rachunkach numerycznych najlepiej przedstawić w postaci stabelaryzowanej (tab. 1).

\section{Wyniki badań i dyskusja}

Wstępne oględziny pompowtryskiwaczy nie wykazały uszkodzeń zewnętrznych i braku elementów składowych. Po- 
unit injector systems. The results obtained are summarised in Table 2, specifying the data being estimated analytically.

Presentation of the computation process is showed on the example of the last of the designs being tested. In the first place, the first-order and the second-order difference quotients were determined (Tab. 3).

For example, the first element in this table, i.e. the firstorder difference quotient, was determined from the following equation:

$$
f\left(x_{0} ; x_{1}\right)=\frac{f\left(x_{1}\right)-f\left(x_{0}\right)}{x_{1}-x_{0}}
$$

After substituting the numerical values to equation (2), the following was obtained:

$$
\mathrm{f}(400 ; 800)=\frac{34.5-5.0}{800-400}=0.07375
$$

In the next step, the values of interpolation polynomials of the degree $n=2$ were calculated for indirect points. With three main nodes, the formula (1) assumes the following form:

$$
\mathrm{W}_{2}(\mathrm{x})=\mathrm{f}\left(\mathrm{x}_{0}\right)+\mathrm{f}\left(\mathrm{x}_{0} ; \mathrm{x}_{1}\right)\left(\mathrm{x}-\mathrm{x}_{0}\right)+\mathrm{f}\left(\mathrm{x}_{0} ; \mathrm{x}_{1} ; \mathrm{x}_{2}\right)\left(\mathrm{x}-\mathrm{x}_{0}\right)\left(\mathrm{x}-\mathrm{x}_{1}\right)
$$

Hence, for $\mathrm{x}_{1}=500$ the following was obtained:

$$
\begin{aligned}
& \mathrm{W}_{2}(\mathrm{x})=5.0+0.07375(500-400)+ \\
& +\frac{(-4.43182(500-400)(500-800))}{10^{5}}=13.7
\end{aligned}
$$

The value for $x_{3}=1000$ was determined in the similar way:

$$
\begin{aligned}
& \mathrm{W}_{2}(\mathrm{x})=5.0+0.07375(1000-400)+ \\
& +\frac{(-4.43182(1000-400)(1000-800))}{10^{5}}=43.9
\end{aligned}
$$

The accuracy of the calculation procedure can be easily verified by substituting any main operand to the formula (4). In this case, the value of interpolation polynomial should be equal to that being measured at a given measuring point. Figure 2 shows the graphical interpretation of fuel dosing characteristics in the initial test.

The analysis of initial deliveries showed that too low values were obtained for the fuel dosing of unit injector systems No. 1 and 4 in the whole area of engine speeds. miary indukcyjności i oporności wykluczyły awarię cewek elektromagnetycznych, a także ich zwarcie z masą. W związku z tym przystąpiono do fazy testów wstępnych na stole probierczym typu STP-4. Wybór węzłów głównych i punktów pośrednich podyktowany był wyłącznie założeniami procedury, którą wykorzystuje się do sprawdzenia pompowtryskiwaczy firmy Bosch. Uzyskane rezultaty zestawiono w tabeli 2, wyszczególniając dane oszacowane analitycznie.

Table 3. Determination of difference quotients for the results of unit injector system No. 4

Tabela 3. Wyznaczenie ilorazów różnicowych dla wyników pompowtryskiwacza numer 4

\begin{tabular}{|c|c|c|c|}
\hline $\mathrm{x}_{\mathrm{i}}$ & $\mathrm{f}\left(\mathrm{x}_{\mathrm{i}}\right)$ & $\mathrm{f}\left(\mathrm{x}_{\mathrm{i}-1} ; \mathrm{x}_{\mathrm{i}}\right)$ & $\mathrm{f}\left(\mathrm{x}_{\mathrm{n}-2} ; \mathrm{x}_{\mathrm{n}-1} ; \mathrm{x}_{\mathrm{i}}\right)$ \\
\hline 400 & 5.0 & - & - \\
\hline 800 & 34.5 & 0.07375 & - \\
\hline 1500 & 52.0 & 0.025 & $-4.43182 \cdot 10^{-5}$ \\
\hline
\end{tabular}

Prezentację procesu obliczeniowego przedstawiono na przykładzie ostatniej z badanych konstrukcji. W pierwszym rzędzie wyznaczono ilorazy różnicowe pierwszego i drugiego rzędu (tab. 3).

Przykładowo pierwszy człon w tabeli, a więc iloraz różnicowy pierwszego rzędu, wyznaczono z zależności (2). Po podstawieniu wartości liczbowych otrzymano zależność (3). W kolejnym krokuobliczono wartości wielomianów interpolacyjnych stopnia $\mathrm{n}=2$ dla punktów pośrednich. Przy trzech węzłach głównych wzór (1) przyjmuje postać (4) i stąd dla $x_{1}=500$ uzyskano wzór (5). W taki sam sposób oszacowano wartość dla $x_{3}=1000$ - wzór (6).

Poprawność procedury obliczeniowej można sprawdzić, podstawiając dowolny argument główny do wzoru (4). Wtedy wartość wielomianu interpolacyjnego powinna być równa wielkości zmierzonej w danym punkcie pomiarowym. Na rysunku 2 przedstawiono graficzną interpretację charakterystyk dawkowania w teście wstępnym.

Analiza wydatków wstępnych wykazała, iż w całym obszarze prędkości obrotowych uzyskano zbyt niskie wartości dawkowania pompowtryskiwaczy o numerach 1 i 4 . W związku z tym wykreślone krzywe przebiegają poniżej dolnej granicy zakresu dopuszczalnego. Aby ustalić przyczynę nieprawidłowej pracy, przeprowadzono demontaż 


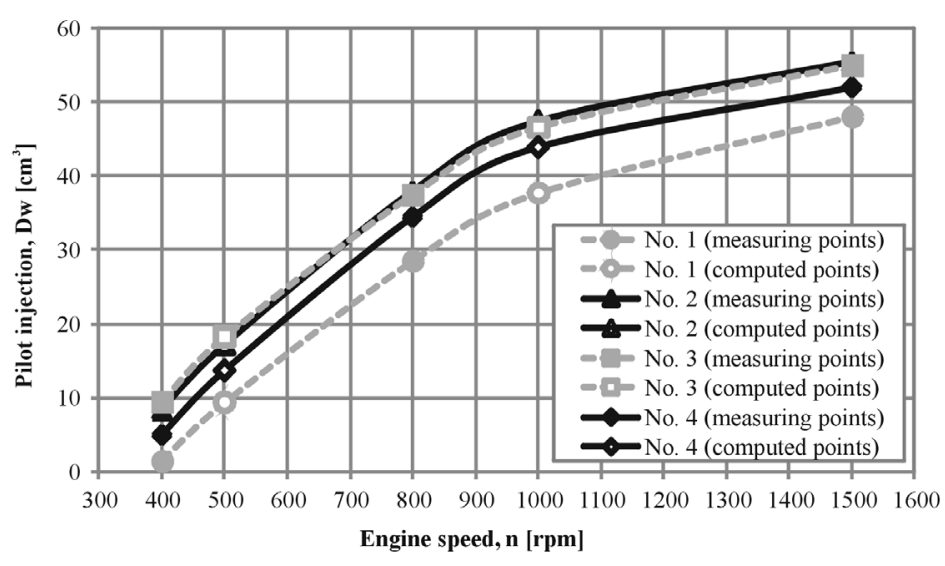

Fig. 2. Fuel dosing characteristics for unit injector systems in the initial test $D_{w}=f(n)$ Rys. 2. Charakterystyki dawkowania pompowtryskiwaczy $w$ teście wstępnym $D_{w}=f(n)$

Therefore, the curves being plotted run below the lower limit of acceptable range. In order to establish the reasons of faulty operation, unit injector system was disassembled into components, which were examined under a microscope (Fig. 3-4).

Deposits were observed on examined parts under high magnification. These deposits develops when engine is fueled with Diesel oil with a large amount of bio components. First, there was a blockage in a number of channels supplying fuel to pumping section chamber. Spray nozzle tips were heavily coked, which may be evidence of the presence of impurities, polymerisation products or free glycerine, remaining after the production process $[5,7,8]$. Furthermore, internal deposits, being termed IDID (Internal Diesel Injector Deposit), were seen on the surfaces of co-operating working parts. Their presence adversely affects the operating efficiency of injection equipment, limiting the dynamics of operation of particular components. As a result, the precision of fuel dosing, both quantitatively and qualitatively, is being disturbed $[1,10]$. On the basis of the examination carried out, the following components were replaced in all designs

a)

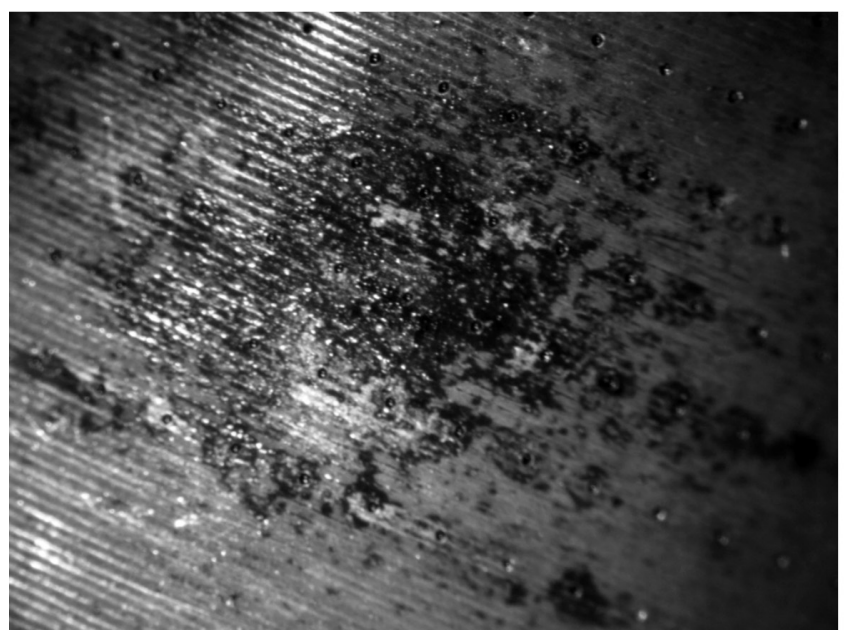

konstrukcji na elementy składowe, które poddano oględzinom mikroskopowym (rys. 3 i 4).

Na częściach badanych pod dużym powiększeniem zaobserwowano osady, które powstają przy zasilaniu silnika olejem napędowym ze znaczną domieszką komponentu roślinnego. Przede wszystkim stwierdzono niedrożność wielu kanałów doprowadzających paliwo do komory sekcji tłoczącej. Końcówki rozpylaczy były bardzo zakoksowane, co może świadczyć o obecności zanieczyszczeń produktów polimeryzacji lub wolnej gliceryny, pozostałej po procesie produkcyjnym $[5,7,8]$. Ponadto na powierzchniach współpracujących elementów roboczych widoczne były osady wewnętrzne, określane IDID (Internal Diesel Injector Deposit). Ich obecność wpływa niekorzystnie na efektywność pracy aparatury wtryskowej, ograniczając dynamikę działania poszczególnych podzespołów. W efekcie zaburzona zostaje precyzja dawkowania paliwa pod względem ilościowym i jakościowym $[1,10]$. Na podstawie przeprowadzonych oględzin we wszystkich badanych konstrukcjach wymieniono: parę precyzyjną (rozpylacz z iglicą), nakrętkę i popychacz. Standardowa procedura wymaga również zastosowania nowej podkładki uszczelniającej, pierścienia zabezpieczającego i zespołu o-ringów (rys. 5). Pozostałe elementy skierowano do półgodzinnego mycia w wannach ultradźwiękowych. Wyjątek stanowiły cewki elektromagnetyczne, które nie były zanurzane w płynie czyszczącym ze względu na możliwość zmiękczenia i uszkodzenia izolacji.

Zgodnie z zaleceniami firmy Bosch ciśnienie otwarcia pompowtryskiwaczy wyregulowano do wartości $18 \mathrm{MPa}$. Wykorzystano do tego celu urządzenie EPS 100 ze specjalnie przeznaczoną do tego obsadą głowicową. Ustalenie omawianego parametru było konieczne przed montażem końcowym oraz przed wykonaniem testów zasadniczych na stole probierczym. Uzyskane rezultaty potwierdziły, iż proces naprawczy przebiegł prawidłowo (tab. 4). Ze względu

b)

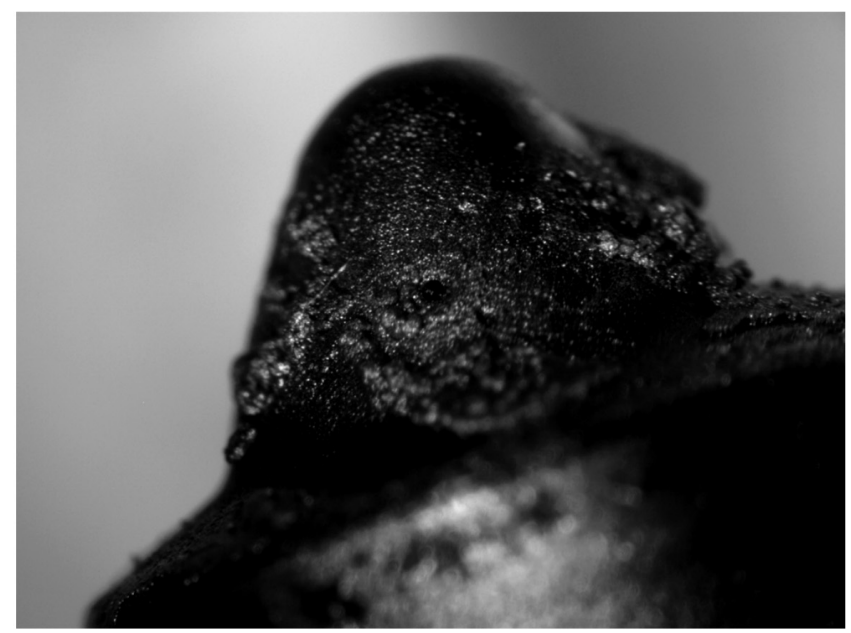

Fig. 3. Examples of deposits on external elements: fuel supplying channels of the nut (a), spray nozzle tip (b) Rys. 3. Przykłady osadów na elementach zewnętrznych: kanaty doprowadzające paliwo w nakrętce (a), końcówka rozpylacza (b) 
a)

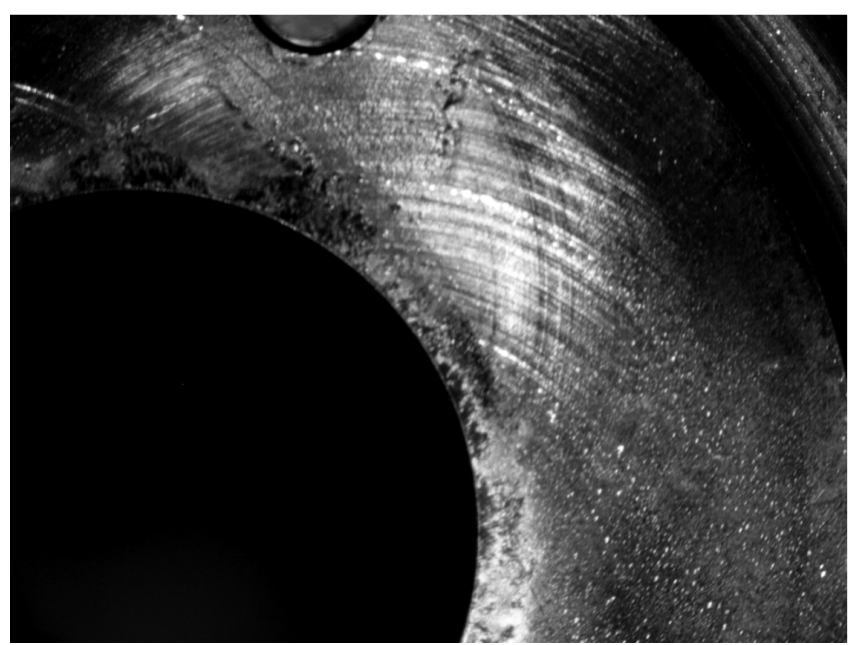

b)

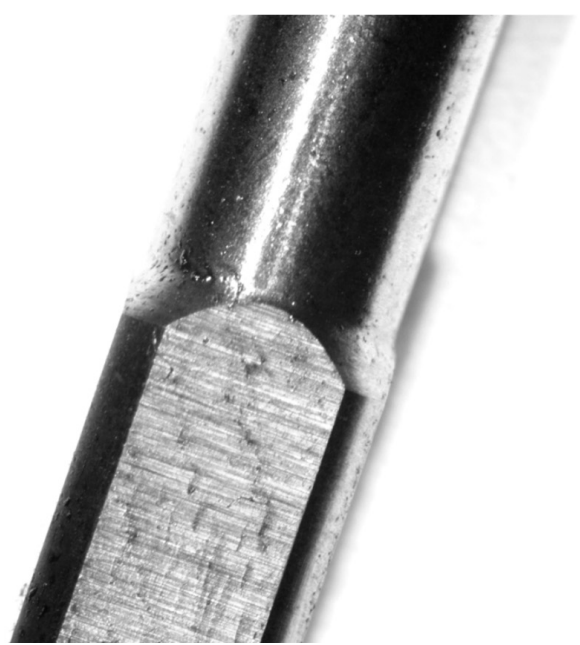

Fig. 4. Examples of deposits on internal elements: hydraulic accumulator socket from the side of spray nozzle (a), spray nozzle pin (b) Rys. 4. Przykłady osadów na elementach wewnętrznych: gniazdo zasobnika hydraulicznego od strony rozpylacza (a), powierzchnia iglicy (b)

being tested: plunger and barrel assembly (spray nozzle with pin), nut and tappet. Standard procedure also requires the application of new seal washer, locking ring and O-ring set (Fig. 5). Other elements were sent to a half-hour washing in ultrasonic bath-tubes. Solenoid coils, which had not been immersed in a cleaning liquid due to possible insulation softening and damage, were an exception.

In conformity with the Bosch recommendations, the opening pressure of unit injector systems was adjusted to $18 \mathrm{MPa}$. For this purpose, a Bosch EPS 100 pressure tester with a specifically dedicated head mounting holder was used. Determination of this parameter was necessary prior to final assembly, as well as before conducting primary tests on a test bench. Obtained results confirm that the repair process was correct (tab. 4). Due to similar values for respective fuel doses, and the same to overlapping of the curves on the diagram, their presentation in the graphical form was omitted. Computations were made in similar way as in the case of initial tests.

Benefits from application of the proposed methodology can be seen reduction of the test stage duration (Fig. 6). The data include 20-second intervals needed for emptying a measuring cylinder and setting next pre-set parameters. Limitation of the number of measuring points shortened the duration of single unit injector system testing by about $38 \%$. In the case of the whole set, verified before and after the repair, the total time of bench tests was shortened by almost an hour and a half (5120 s). The necessary requirement was to transfer manual calculations to the digital environment, i.e. to perform regular computations in any spreadsheet. This way, determination of the values of interpolation polynomials took place after completing respective measurement cycles.

Experimental verification of the interpolation results was possible after making additional measurements at indirect points (Fig. 7). The maximal value of error, which is $50 \%$ of the scale interval $0.5 \mathrm{~cm}^{3}$ for a measuring cylinder, na zbliżone wartości poszczególnych dawek, a tym samym nakładanie się krzywych na wykresie, zrezygnowano z ich prezentacji w formie graficznej. Obliczenia przeprowadzono w taki sam sposób jak dla testów wstępnych.

Korzyści z zastosowania proponowanej metodyki można zauważyć, jeśli rozpatrzy się czasochłonność fazy testowej (rys. 6). W zestawieniu uwzględniono 20-sekundowe przerwy, potrzebne na opróżnianie cylindra mierniczego i nastawy kolejnych parametrów zadanych. Ograniczenie liczby punktów pomiarowych skróciło badanie pojedynczego pompowtryskiwacza o ok. 38\%. Dla całego kompletu, sprawdzanego przed i po naprawie, sumaryczny czas testów probierczych zmniejszył się o prawie półtorej godziny (5120 s). Warunkiem koniecznym było przeniesienie rachunków ręcznych do środowiska cyfrowego, a więc prowadzenie bieżących obliczeń w dowolnym arkuszu kalkulacyjnym. W ten sposób wyznaczanie wartości wielomianów interpo-

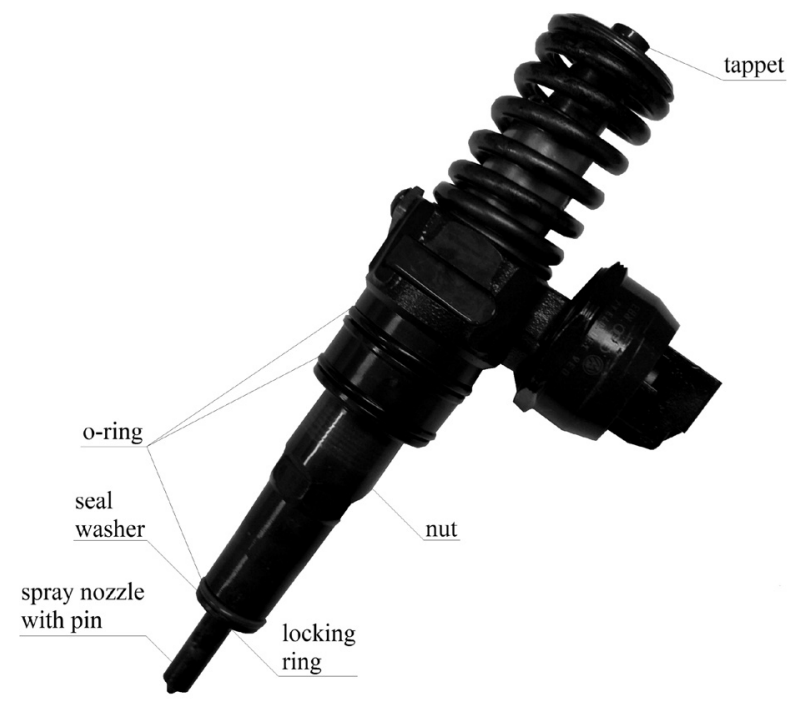

Fig. 5. A view of unit injector system with mentioned elements Rys. 5. Pompowtryskiwacz z wyszczególnieniem wymienionych elementów 
Table 4. Results of primary tests and computations for the unit injector systems being tested

Tabela 4. Wyniki testów zasadniczych i obliczeń badanych pompowtryskiwaczy

\begin{tabular}{|c|c|c|c|c|c|c|}
\hline \multirow[t]{2}{*}{ No. } & \multirow{2}{*}{$\begin{array}{c}\text { Engine speed/ } \\
\text { prędkość obrotowa } \\
\mathrm{n}[\mathrm{rpm}]\end{array}$} & \multicolumn{5}{|c|}{ Fuel injection amount/wielkość dawki $\mathrm{D}_{\mathrm{w}}\left[\mathrm{cm}^{3}\right]$} \\
\hline & & No. 1 & No. 2 & No. 3 & No. 4 & $\begin{array}{l}\text { Acceptable range/ } \\
\text { zakres dopuszczalny }\end{array}$ \\
\hline 1 & 400 & 9.0 & 10.0 & 10.5 & 9.0 & $6.0-13.0$ \\
\hline $2 *$ & 500 & 17.5 & 18.3 & 18.6 & 17.3 & $17.0-21.5$ \\
\hline 3 & 800 & 38.0 & 38.5 & 38.5 & 37.5 & $36.0-41.0$ \\
\hline $4^{*}$ & 1000 & 47.5 & 47.9 & 47.9 & 47.0 & $43.0-48.0$ \\
\hline 5 & 1500 & 56.5 & 57.0 & 58.0 & 57.0 & $55.0-62.0$ \\
\hline
\end{tabular}

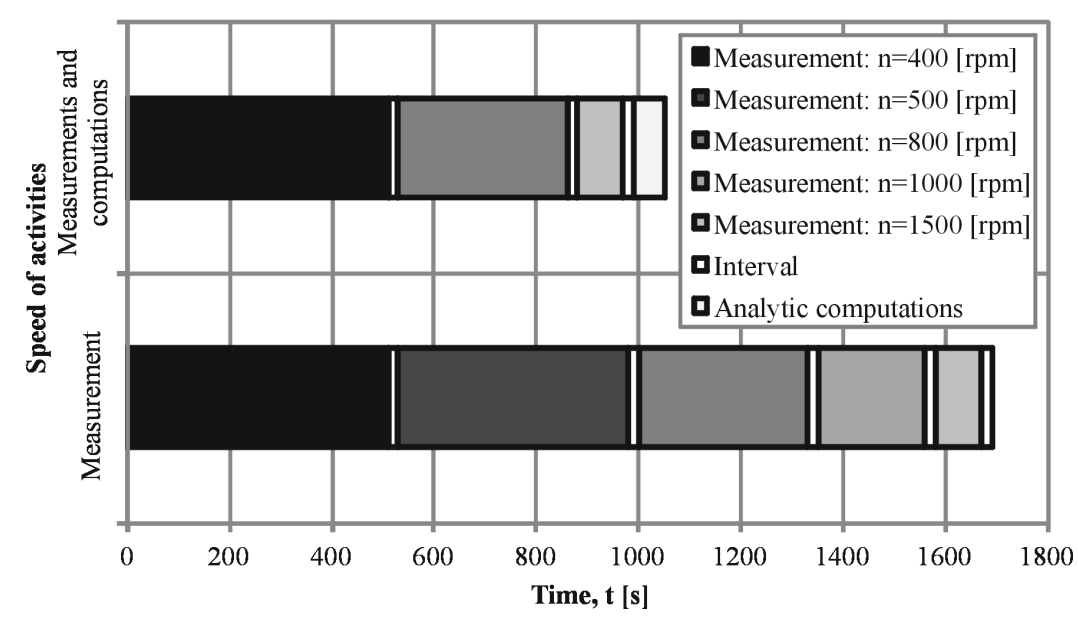

Fig. 6. Unit injector system test time consumption in the standard method and that allowing for analytic computations

Rys. 6. Czasochtonność testu pompowtryskiwacza w metodzie standardowej i uwzględniajacej obliczenia analityczne

was not exceeded in any considered case. Furthermore, the selection of interpolation method and the use of low-degree polynomials limited the risk of undesirable interference or oscillation. Worsening of the approximation, particularly at the ends of discrete intervals, is usually observed for a large number of main nodes and preservation of a constant distance between them, i.e. the so called Runge phenomenon [2, 3]. a)

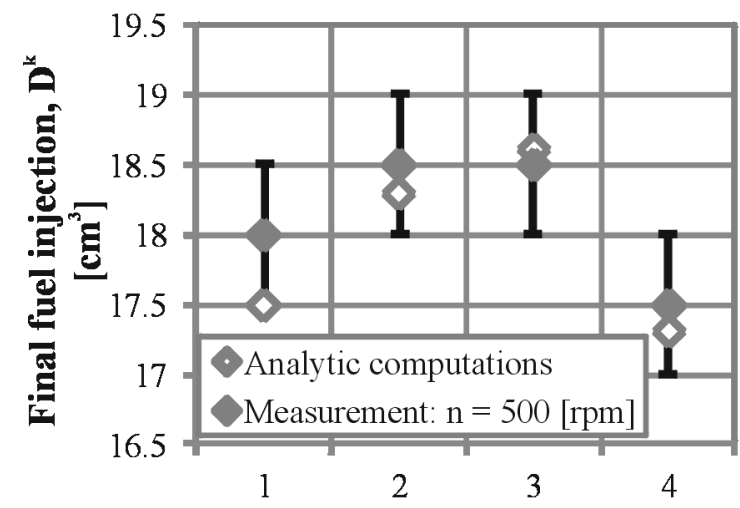

Unit injector system number

\section{Wnioski}

b) lacyjnych odbywało się po zakończeniu poszczególnych cykli pomiarowych.

Doświadczalna weryfikacja wyników interpolacji możliwa była po wykonaniu dodatkowych pomiarów w punktach pośrednich (rys. 7). W żadnym $\mathrm{z}$ rozpatrywanych przypadków nie została przekroczona graniczna wartość błędu, który dla cylindra miarowego stanowi 50\% elementarnej działki: $0,5 \mathrm{~cm}^{3}$. Ponadto wybór metody interpolacyjnej i wykorzystanie wielomianów niskich stopni ograniczyło ryzyko wystąpienia niepożądanych zakłóceń czy oscylacji. Pogorszenie przybliżenia, szczególnie na końcach przedziału dyskretnego, obserwuje się zwykle przy dużej liczbie węzłów głównych i zachowaniu stałej odległości między nimi, tzw. efekt Rungego [2, 3].

Wyniki przeprowadzonej analizy wskazują, iż metodyka bazująca na wzorze interpolacyjnym Newtona może być przydatna $\mathrm{w}$ testowaniu omawianej aparatury wtryskowej. Jej wykorzystanie efektywnie wspomaga ten proces, gdyż oszacowanie brakujących danych nie nastręcza problemów

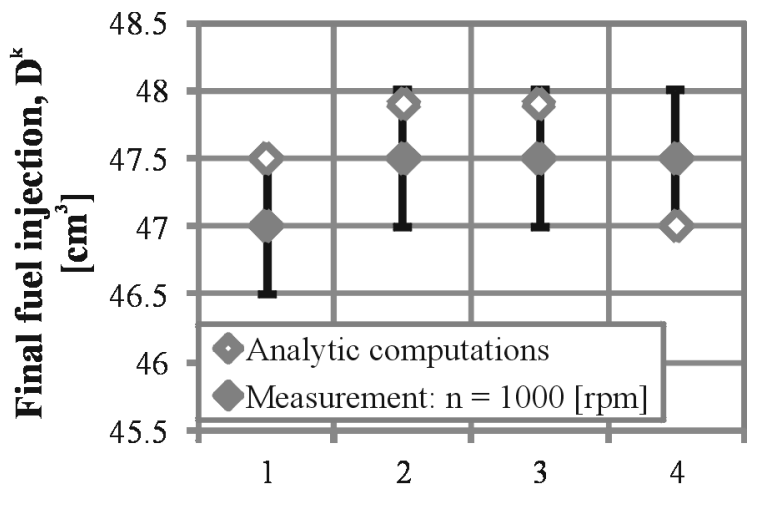

Unit injector system number

Fig. 7. Comparison of the values of measured fuel doses and those being calculated in the final test for indirect operands: $\mathrm{n}=500 \mathrm{rpm}(\mathrm{a}), \mathrm{n}=1000 \mathrm{rpm}(\mathrm{b})$ Rys. 7. Porównanie wartości dawek zmierzonych i obliczonych w teście końcowym dla argumentów pośrednich: $n=500$ obr/min (a), $n=1000 \mathrm{obr} / \min (\mathrm{b})$ 


\section{Conclusions}

The results analysis show that the methodology based on the Newton's interpolation formula may be useful in discussed testing of the injection equipment. Its use effectively supports this process because estimation of the missing data does not pose any technical problems. As a result, the time of making measurements, which are particularly burdensome due to noisiness of unit injector system operation, is being shortened. In this aspect, even greater benefits are being obtained for power units with a larger number of cylinders.

The formulas being introduced into a spreadsheet can be applied in the testing of designs of other types, generations or manufacturers, including UPS (Unit Pump System) sets. This is because a change in the input parameters comes down to introduction of new measuring points, followed by calculation of the values of polynomial for any indirect operands. Such an approach is more convenient from the practical side because it eliminates the necessity of searching for the final form of the interpolation function. Furthermore, increasing the number of main nodes does not require recalculation of the existing difference quotients, while adaptation of the mathematical algorithm for higher degree polynomials is intuitive. od strony technicznej. W rezultacie skrócony zostaje czas prowadzenia pomiarów, które są szczególnie uciążliwe ze względu na hałaśliwość pracy pompowtryskiwaczy. W tym aspekcie jeszcze większe korzyści uzyskuje się dla jednostek napędowych o większej liczbie cylindrów.

Formuły wprowadzone w arkusz kalkulacyjny moga znaleźć bezpośrednie zastosowanie w badaniach konstrukcji innych typów, generacji czy producentów, w tym dla zespołów UPS (Unit Pump System). Zmiana parametrów wejściowych sprowadza się bowiem do wprowadzenia nowych punktów pomiarowych, a następnie obliczenia wartości wielomianu dla dowolnych argumentów pośrednich. Takie podejście jest wygodne od strony praktycznej, gdyż eliminuje konieczność poszukiwania końcowej postaci funkcji interpolującej. Ponadto zwiększanie liczby węzłów głównych nie wymaga ponownego przeliczania istniejących ilorazów różnicowych, a dostosowanie algorytmu matematycznego do wielomianów wyższych stopni odbywa się w sposób intuicyjny.

\section{Bibliography/Literatura}

[1] Caprotti R., Bhatti N., Balfour G.: Deposit Control in Modern Diesel Fuel Injection Systems. SAE Technical Paper 2010, 2010-01-2250.

[2] Cheney W., Kincaid D.: Numerical Mathematics and Computing. Belmont: Thompson Learning. Inc., 2008.

[3] Fausett L.,V.: Applied numerical analysis using Matlab®. New Jersey: Pearson Education. Inc., 2008.

[4] Forzatti P., Lietti L., Nova I., Tronconi E.: Diesel NOx aftertreatment catalytic technologies: Analogies in LNT and SCR catalytic chemistry. Catalysis Today, 151/2010.

[5] Galle J., Verhelst S., Sierens R., Goyos L., Castaneda R., Verhaege M., Vervaeke L., Bastiaen M.: Failure of fuel injectors in a medium speed diesel engine operating on bio-oil. Biomass and Bio-energy, 40/2012.

[6] Günther H.: Common Rail - Systeme in der Werkstattpraxis. Technik, Prüfung, Diagnose. Bad Wörihofen: Krafthand Verlag Walter Schultz GmbH, 2012.

[7] Hussan M.J., Hassan M.H., Kalam M.A., Memon L.A.: Tailoring key fuel properties of diesel-biodiesel-ethanol blends for diesel engine. Journal of Cleaner Production, 51/2013.

[8] Jayed M.H., Masjuki H.H., Saidur R., Kalam M.A., Jahirul M.I.: Environmental aspects and challenges of oilseed produced biodiesel in Southeast Asia. Renewable and Sustainable Energy Reviews, 13/2009.

Tomasz Stoeck, DEng. - doctor in the Department of Automotive Engineering at West Pomeranian University of Technology in Szczecin.

Drinż. Tomasz Stoeck-adiunkt w Katedrze Eksploatacji Pojazdów Samochodowych Zachodniopomorskiego Uniwersytetu Technologicznego w Szczecinie.

e-mail: tstoeck@wp.pl
[9] Knefel T.: Technical assessment of Common Rail injectors on the ground of overflow bench tests. Eksploatacja i Niezawodnosc - Maintenance and Reliability, 1/2012.

[10] Quigley R., Barbour R., Fahey E., Arters D., Wetzel W., Ray J.: A Study of the Internal Diesel Injector Deposit Phenomenon. TAE International Colloquium: Fuels-Conventional and Future Energy for Automobiles, 8/2011.

[11] Stoeck T., Abramek K.F.: Application of the polynomial interpolation method for determining performance characteristics of a diesel engine. Metrology and Measurement Systems, vol. XXI, $1 / 2014$.

[12] Stoeck T., Osipowicz T., Abramek K.F.: Methodology for the repair of Denso Common Rail solenoid injectors. Eksploatacja i Niezawodnosc - Maintenance and Reliability, 2/2014.

[13] Weiss M., Bonnel P., Kühlwein J., Provenza A., Lambrecht U., Alessandrini S., Carriero M., Colombo R., Forni F., Lanappe G., Le Lijour P., Manfredi U., Montigny F., Sculati M.: Will Euro 6 reduce the NOx emissions of new diesel cars? Insights from on-road tests with Portable Emissions Measurement Systems (PEMS). Atmospheric Environment, 62/2012.

[14] Yang W.Y., Cao W., Chung T., Morris J.: Applied Numerical Methods Using Matlab ${ }^{\circledR}$. New Jersey: John Wiley \& Sons. Inc., 2005.
Tomasz Osipowicz, DEng. - doctor in the Department of Automotive Engineering at West Pomeranian University of Technology in Szczecin.

Drinż. Tomasz Osipowicz-adiunkt w Katedrze Eksploatacji Pojazdów Samochodowych Zachodniopomorskiego Uniwersytetu Technologicznego w Szczecinie. e-mail:Tomasz.Osipowicz@zut.edu.pl

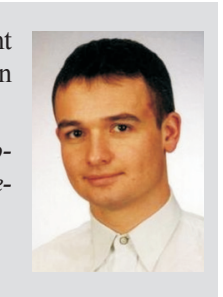

